\title{
Bacterial Resistance Finish on Cotton Fabric with Pomegranate and Onion Peel Extracts
}

\author{
Neeta Singh ${ }^{1 *}$, Parveen Punia ${ }^{2}$ and Vivek Singh ${ }^{2}$ \\ ${ }^{1}$ Department of Textiles and Apparel Designing, Sardar Krushi Nagar Dantiwada Agricultural \\ University, SK Nagar- 385 506, Gujarat, India \\ ${ }^{2}$ Department of Textiles and Apparel Designing, Chaudhary Charan Singh Haryana Agricultural \\ University, Hisar-125 004, Haryana, India \\ *Corresponding author
}

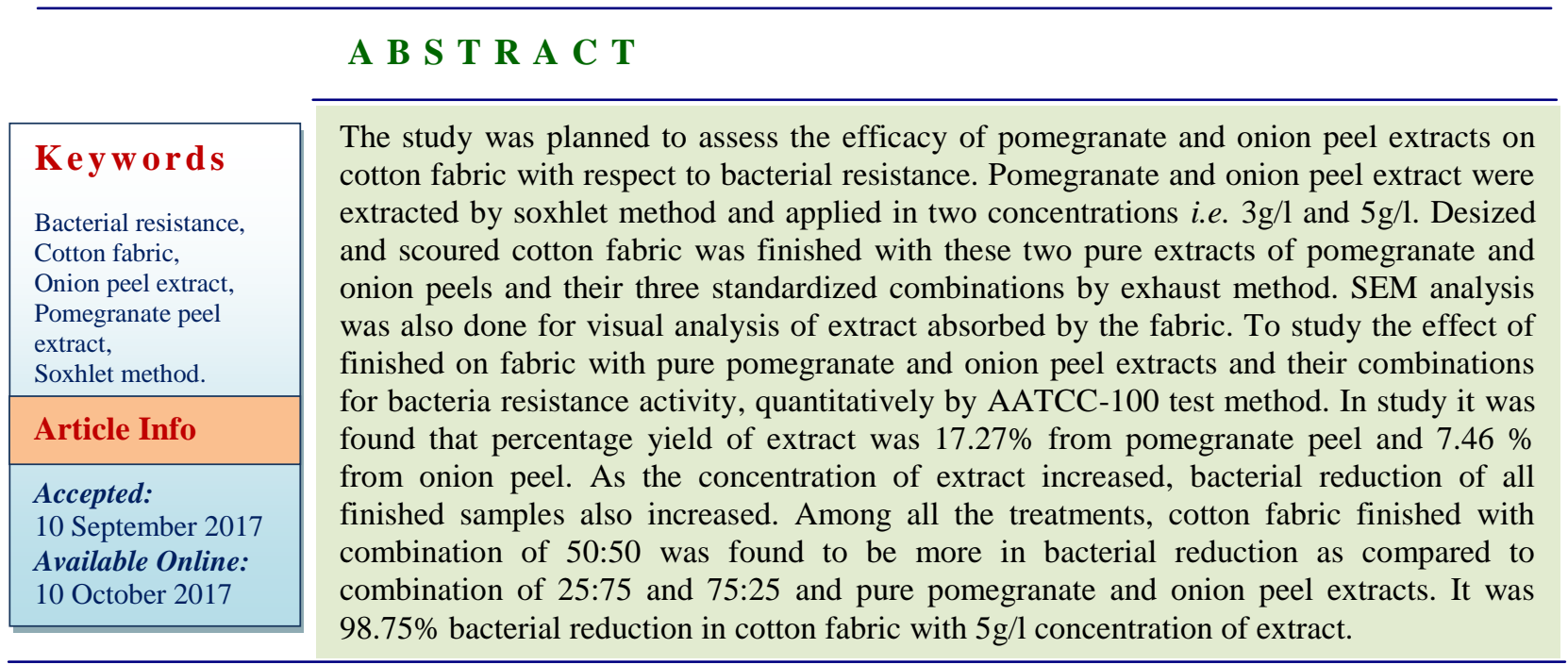

\section{Introduction}

Microbial action is a dominant factor for limiting the service life of all textiles. Biodegradation of textiles is prevalent under tropical conditions. Textile materials and garments are susceptible to microbial attack, as these provide large surface area and absorb moisture required for microbial growth (Cardamone, 2002). Fabrics made from natural fibers are in demand due to their inherent properties like comfortability, good absorbency and being eco-friendly. These fibers are susceptible to microbial attack due to presence of waxes, pectin, cellulose and protein. Cotton fabrics are sensitive to bacterial attack and susceptible to micro-organisms growth due to their hydrophobic nature. Additionally, direct contact of textiles with human body provides warmth, humidity and nutrients; an excellent environment for microorganism growth on textiles, resulting in unpleasant odor spread of diseases, discoloration, staining and degradation of cotton textiles. Understanding the importance of use of cotton fabric in our day to day life and considering the significance of antimicrobial finish on textiles, to overcome consumer 
health problems faced by the consumers due to environment hazards like microbes, it is of great concerns to use of discarded underutilized parts of fruits and vegetables. Underutilized parts of plants means the parts used less than fully or below the potential and not used as much as it could be. The discarded or left over portions of the plant like seed, peels and skins can be reused for both environment and economic benefits. These parts can also be used to create value added products.

\section{Materials and Methods}

Pure cotton fabric and two underutilized peels each from the exhaustive lists of fruits and vegetables i.e. pomegranate and onion were selected on the basis of survey and collected from the Hisar market. Use of these selected underutilized peels of pomegranate and onion for the preparation of extracts by soxhlet method. Exhaust method was used for the application of two pure extracts of pomegranate and onion peel and their standardized combinations i.e. 50:50, 25:75 and $75: 25$ on the desized and scoured cotton fabric in two concentrations i.e. $3 \mathrm{~g} / \mathrm{l}$ and $5 \mathrm{~g} / \mathrm{l}$. The surface morphological structure and characteristic of all finished and controlled samples of cotton fabric were analyzed by Scanning Electron Microscope (Philips XL 30) with an accelerating voltage of $10 \mathrm{kv}$ for magnification. To study the effect of finished cotton samples with pure pomegranate and onion peel extracts and their combinations for bacterial resistance activity, quantitatively by AATCC-100 test method.

\section{Results and Discussion}

Determination of yield percentage of pomegranate and onion peel extracts

The results it was found that the yield percent of pomegranate and onion peel extracts were obtained by soxhlet method from air dried powder of the peels for 8 hours was $17.27 \%$ and $7.46 \%$, respectively and showed in table 1. Thus, yield percentage of pomegranate peel extract was found to be higher as compared to yield percentage of onion peel extracts. The air dried powder weight of the onion peel was less as compared to air dried powder weight of pomegranate peel. The difference in the yield percentage of extract may due to the variation of chemical composition and also due to the difference in the physical and chemical properties such as solubility of compound present in the peel of the pomegranate and onion.

\section{Scanning Electron Microscopic (SEM) analysis of finished and controlled fabrics}

The surface morphological structure of controlled (unfinished) and finished samples of cotton fabrics were analyzed by Scanning Electron Microscope (Philips XL 30) and are showed in the plate 2 . It was showed that unfinished cotton fabric depicted the smooth surface of fiber with striation while slight deposition of extracts of pomegranate and onion peel on the surface of finished cotton fabric. It can be clearly seen that extract of pomegranate and onion peel were deposited unevenly in the form of granule on the surface of the fabric and it was not found on the surface of unfinished cotton fabric.

Surface morphology features of the cotton fabric finished with combinations extract of pomegranate and onion peel were analyzed and these were showed in plate 1. It was found that cotton fabric finished with 50:50, 25:75 and 75:25 combinations showed more granules on the surface of fabric, as compared to unfinished and finished fabric with pure pomegranate and onion peel extracts. Fibers of cotton fabric depicted the puckering effect. The may be due to the acidic reaction of the extract on the fiber. 


\section{Determination of bacterial resistance of the} finished fabrics

To determine the bacterial resistance of the fabrics finished with pomegranate and onion peel extracts and their combinations in two different concentrations i.e. $3 \mathrm{~g} / 1$ and $5 \mathrm{~g} / 1$ by exhaust method, the growth of $E$. coli bacteria was counted quantitatively by AATCC-100 test method. The efficacy of pomegranate and onion peel extracts and their combinations was compared against the control sample and also among themselves. Bacterial reductions of finished cotton fabric are given in table 2 .

It is evident from the data that there was confluent lawn of growth of bacteria on the control sample. After finishing the cotton fabric by exhaust method with $3 \mathrm{~g} / 1$ and $5 \mathrm{~g} / \mathrm{l}$ concentrations of pomegranate peel extract separately, percentage reduction values were
$97.08 \%$ and $97.92 \%$, respectively. Data also revealed that when onion peel extract was applied by exhaust method with $3 \mathrm{~g} / \mathrm{l}$ and $5 \mathrm{~g} / \mathrm{l}$ concentrations, the percent reduction values were $97.00 \%$ and $97.58 \%$, respectively.

Data also depicted the bacterial reduction against various combinations of pomegranate and onion peel extracts. It was found that 50:50 combination of pomegranate and onion peel extract exhibited maximum bacterial reduction i.e. $98.58 \%$ with $3 \mathrm{~g} / \mathrm{l}$ concentration by exhaust method followed by $75: 25$ and 25:75 combinations with $97.83 \%$ and $97.42 \%$ bacterial reduction, respectively. With $5 \mathrm{~g} / \mathrm{l}$ concentration of the same extract i.e. pomegranate and onion peel extracts, the bacterial reduction values increased to $98.75 \%, 98.16 \%$ and $98.00 \%$ using 50:50, 75:25 and 25:75 standardized combinations on cotton fabric.

Plate.1 SEM analysis of finished and controlled fabric

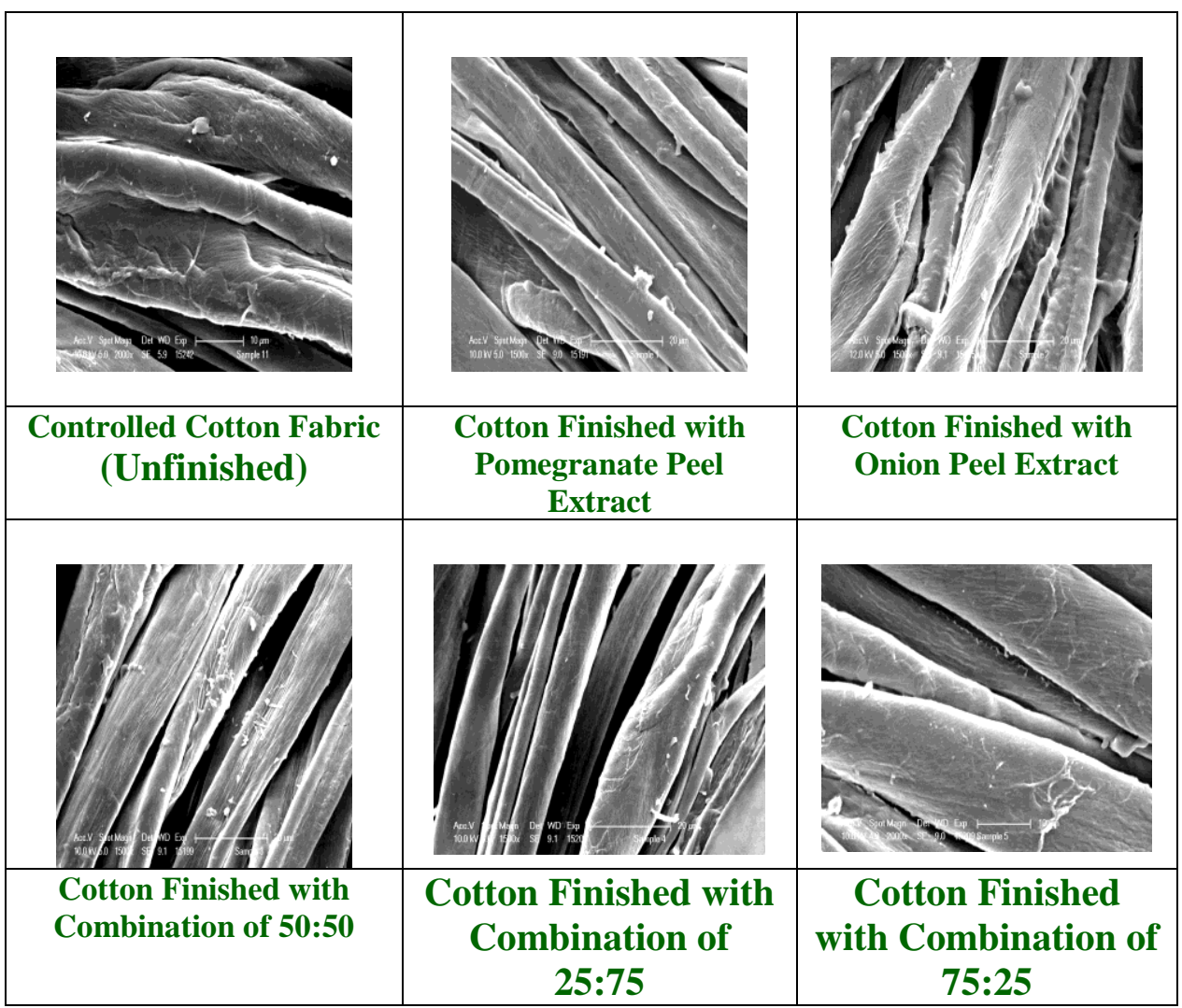


Table.1 Determination of yield percentage of pomegranate and onion peel extract

\begin{tabular}{|l|c|c|c|c|c|}
\hline $\begin{array}{l}\text { Underutilized } \\
\text { peels }\end{array}$ & $\begin{array}{c}\text { Weight of } \\
\text { air dry } \\
\text { powder }(\mathbf{g})\end{array}$ & $\begin{array}{c}\text { Method of } \\
\text { extraction }\end{array}$ & $\begin{array}{c}\text { Time period } \\
\text { of extraction } \\
\text { (hours) }\end{array}$ & $\begin{array}{c}\text { Weight of } \\
\text { the extract } \\
\text { (g) }\end{array}$ & $\begin{array}{c}\text { Percentage } \\
\text { yield }\end{array}$ \\
\hline Pomegranate Peel & 134 & Soxhlet & 8 & 23.14 & 17.27 \\
\hline Onion Peel & 134 & Soxhlet & 8 & 10.00 & 7.46 \\
\hline
\end{tabular}

Table.2 Determination of bacterial reduction of cotton fabric finished with pomegranate and onion peel extracts by quantitative method

\begin{tabular}{|c|c|c|c|c|c|c|}
\hline \multirow{3}{*}{$\begin{array}{l}\text { Application } \\
\text { Method }\end{array}$} & \multirow{3}{*}{$\begin{array}{c}\text { Concentration } \\
\text { of extracts } \\
(\mathrm{g} / \mathrm{l})\end{array}$} & \multicolumn{5}{|c|}{ Bacterial count (CFU/ml) (\% Reduction) (Escherichia coli) } \\
\hline & & \multirow{2}{*}{$\begin{array}{c}\text { Pomegranate } \\
\text { peel extract }\end{array}$} & \multirow{2}{*}{$\begin{array}{l}\text { Onion peel } \\
\text { extract }\end{array}$} & \multicolumn{3}{|c|}{$\begin{array}{c}\text { Combinations of pomegranate and } \\
\text { onion peel extracts }\end{array}$} \\
\hline & & & & $(50: 50)$ & $(25: 75)$ & $(75: 25)$ \\
\hline \multirow{2}{*}{$\begin{array}{l}\text { Exhaust } \\
\text { Method }\end{array}$} & 3 & $\begin{array}{l}3.5 \times 10^{6} \\
(97.08 \%)\end{array}$ & $\begin{array}{l}3.6 \times 10^{6} \\
(97.00 \%)\end{array}$ & $\begin{array}{l}1.7 \times 10^{6} \\
(98.58 \%)\end{array}$ & $\begin{array}{l}3.1 \times 10^{6} \\
(97.42 \%)\end{array}$ & $\begin{array}{l}2.6 \times 10^{6} \\
(97.83 \%)\end{array}$ \\
\hline & 5 & $\begin{array}{l}2.5 \times 10^{6} \\
(97.92 \%)\end{array}$ & $\begin{array}{l}2.9 \times 10^{6} \\
(97.58 \%)\end{array}$ & $\begin{array}{l}1.5 \times 10^{6} \\
(98.75 \%)\end{array}$ & $\begin{array}{l}2.4 \times 10^{6} \\
(98.00 \%)\end{array}$ & $\begin{array}{l}2.2 \times 10^{6} \\
(98.16 \%)\end{array}$ \\
\hline $\begin{array}{c}\text { Control } \\
\text { (Unfinished) }\end{array}$ & \multicolumn{6}{|c|}{ Confluent growth } \\
\hline
\end{tabular}

On comparing the efficacy of all cotton finished samples among themselves and with control sample with pure extracts of pomegranate and onion peel, their combinations, different concentrations, it can be concluded that cotton fabrics finished with different combinations of pomegranate and onion peel extracts i.e. 50:50, 25:75 and 75:25 showed better efficacy against bacterial growth as compared to pure pomegranate and onion peel extracts in both concentrations in exhaust methods. As the concentration of pure extracts and their standardized combinations increased, bacterial reduction also increased. This is supported by the study of Jothi (2009), Rathinamoorthy et al., (2012) and Fadhel et al., (2012).

The efficacy of 50:50 combinations of pomegranate and onion peel extracts was maximum than efficacy of the extract in 25:75 and 75:25 combination of the pomegranate and onion peel extract. This is may be due to cumulative effect and different chemical composition of pomegranate and onion peel extracts. Further the efficacy of pure pomegranate peel extract in all treatments against bacterial reduction was determined higher than pure onion peel extract and this is may be due the chemical composition of pomegranate peel extracts i.e. presence of hydrolysable tannins class compound and flavonoids which are known to exhibit a remarkable degree of antibacterial activity.

These results are supported by the study conducted by Khurshid et al., (2015) who stated that bleached cotton samples were treated with 5,7 , and $10 \%$ concentrations of aloe gel and neem separately and also with a hybrid combination of aloe gel and neem (HCAN) extracts in same concentrations. These finished samples were subjected to an antibacterial activity test against $E$. coli and $S$. aureus and an antifungal activity test against Aspergillus niger. It was found that the hybrid combination of aloe gel and neem (HCAN) was an effective antibacterial and antifungal agent as compared to aloe gel and neem separately. These results are in accordance with Al Laham et al., (2014) and Mahajan et al., (2014) who studied antimicrobial activity 
of various parts of Punica granatum against antibiotics resistance $E$. coli, S. aureus, Shigella flexneri and Candida albicans and found that a combination of promising antibacterial extracts has exerted synergistic effect against $E$. coli. Bakarnga et al., (2016) also stated that extracts from different plant parts might be used in combination to achieve improved antibacterial potency.

Thus, yield percentage of pomegranate peel extract was found to be higher as compared to yield percentage of onion peel extract. It can also be concluded that cotton fabrics finished with different combinations of pomegranate and onion peel extracts i.e. 50:50, 25:75 and 75:25 showed better efficacy against bacterial growth as compared to pure pomegranate and onion peel extracts in both concentrations in exhaust methods. As the concentration of pure extracts and their standardized combinations increased, bacterial reduction also increased.

\section{Acknowledgement}

This study was acknowledged to my guide Dr. Parveen Punia of the Department of Textiles and Apparel Designing, who gave the idea for utilization underutilized peel of fruits and vegetables for antibacterial finishing on the textiles.

\section{References}

Al Laham, S., Al Fadel, F. and Al Khatib, R. 2014. The anti-bacterial activity of various parts of Punica granatum on antibiotics resistance Escherichia coli. International
Journal of Pharmacognosy and Phytochemical Research 6(1): 79-85.

Bakarnga Via, Yande, H. K., Kouipou, R. M. T., Kanko, M. I. M., Arc En Ce, J.M., Kammalac, T. N. and Boyom, F. F. 2016. Effect of combined extracts from different plant parts of Annona senegalensis on antibacterial and antifungal activities. International Journal of Pharmacognosy and Phytochemical Research 8(1): 162-166.

Cardamone, J. M., 2002. Proteolytic activity of Aspergillus flavus on wool. AATCC Rev., 61 (2): 30-35.

Fadel, B. B., Aissi, A., Ladhari, N., DeghrigInsue, M., Chemli, R. and Joly, J. P. 2012. Antibacterial effect of two Tunisian eucalyptus leaf extract on wool and cotton fabrics. Journal of the Textile Institute 103(11): 1197-1204.

Jothi, D., 2009. Experimental study on antimicrobial activity of cotton fabric treated with aloe gel extract from Aloe vera plant for controlling the Staphylococcus aureus (bacterium). African Journal of Microbiology Research 3(5): 228-232.

Khurshid, M. F., Ayyoob, M., Asad, M. and Shah, S. N. H. 2015. Assessment of eco-friendly natural antimicrobial textile finish extracted from aloe vera and neem plants. Fibres \& Textiles in Eastern Europe 6(114): 120-123.

Mahajan, D. C., Satyapal, U. S., Tatke, P. A. and Naharwar, V. 2014. Antimicrobial and anthelmentic activity of Punica granatum fruit peel extracts. International Journal of Pharmacognosy and Phytochemical Research 6(3): 482-487.

Rathinamorthy, R., Udaykumar, S. and Thilagavathi, G. 2012. Antibacterial efficacy of Terminalia chebula fruit extract treated cotton fabric for healthcare application. International Journal of Pharmaceutical Sciences and Nanotechnology 4(4): 1549-1556.

\section{How to cite this article:}

Neeta Singh, Parveen Punia and Vivek Singh. 2017. Bacterial Resistance Finish on Cotton Fabric with Pomegranate and Onion Peel Extracts. Int.J.Curr.Microbiol.App.Sci. 6(10): 10751079. doi: https://doi.org/10.20546/ijcmas.2017.610.130 